\title{
A comparative study of carbohydrate antigen 19-9 in sickle cell disease subjects and controls in Nnamdi Azikiwe University Teaching Hospital, Nnewi, Nigeria
}

\author{
Patrick Manafa ${ }^{1}$, Chide Okocha ${ }^{2}$, Benedict Nwogho ${ }^{3}$, John Aneke ${ }^{2}$, \\ Paul Smith Davis Okpara ${ }^{1}$, Nancy lbeh $^{1}$, George Chukwuma ${ }^{1}$, Vera Manafa ${ }^{4}$, Ejike Nwane ${ }^{1}$
}

1. Medical laboratory Science department, College of Health Sciences, Nnamdi Azikiwe University, Nnewi Campus, Anambra State Nigeria.

2. Haematology Department, Nnamdi Azikiwe University Teaching Hospital ,PMB 5025, Nnewi, Anambra State, Nigeria.

3. Haematology Department, College of Medical Sciences, University of Benin, Edo State, Nigeria

4. Chemical Pathology department, Nnamdi Azikiwe University Teaching Hospital, PMB 5025, Nnewi, Anambra State, Nigeria

5. Global Initiative for Health in Nigeria, Enugu, Enugu State, Nigeria

\section{Emails:}

Patrick Manafa: manafatpat@yahoo.com, Chide Okocha: onyichideokocha@yahoo.com, Benedict Nwogho: benedict.nwogoh@uniben.edu, John Aneke: anekejc@ymail.com, Paul Smith Davis Okpara: okparaandy@yahoo.com, Nancy lbeh: nancyibeh@yahoo.com, George Chukwuma: georgechuma@yahoo.com, Vera Manafa: manafavera@ gmail.com, Ejike Nwane: Ihv@gmail.com

\begin{abstract}
Background: Sickle cell disease is characterized by chronic complications that affect almost all body organs. Pancreatic disease is rare in SCD. CA 19-9 is a non-specific surrogate marker for pancreatic disease especially carcinoma. CA 19-9 levels have not been evaluated in SCD patients in our environment.

Objectives: The study aimed to compare the levels of CA 19-9 in homozygous sickle cell disease subjects in steady state with those of ( $\mathrm{Hb} \mathrm{AS}$ ) and normal healthy subjects ( $\mathrm{Hb} \mathrm{AA})$

Method: Seventy nine subjects including $39 \mathrm{Hb} \mathrm{SS}, 19 \mathrm{Hb}$ AS and $21 \mathrm{Hb}$ AA subjects were recruited in a cross-sectional study in Nnamdi Azikiwe University and Teaching Hospital. Haemoglobin genotype and CA 19-9 estimation were done using Hb electrophoresis and enzyme linked immunosorbent assay respectively. Data was analyzed with IBM SPSS 21. P value was set at 0.05 . Result: The mean CA 19-9 (U/ml) level in Hb SS, Hb AS and Hb AA were 13.6 \pm 7.6, $15.3 \pm$ 9.9, and $20.0 \pm 15.9$ respectively. [Reference value <37U/ml] CA 19-9 was significantly lower in Hb SS compared to Hb AA subjects ( $\mathrm{p}=0.035)$.

Conclusion: Low levels of CA 19-9 in Hb SS may suggest reduced pancreatic disorders in SCA.

Keywords: Hemoglobin phenotype, disease severity, carbohydrate antigen 9-19, pancreatic disease, sickle cell disease.

DOI: https://dx.doi.org/10.4314/ahs.v18i4.21

Cite as: Manafa P, Okocha C, Nwogho B, Aneke J, Okpara PSD, lbeh N, Chukwuma G, Manafa V, Nwane E. A comparative study of carbohydrate antigen 19-9 in sickle cell disease subjects and controls in Nnamdi Azikiwe University Teaching Hospital, Nnewi, Nigeria. Afri Health Sci. 2018;18(4): 1003-1009. https://dx.doi.org/10.4314/ahs.v18i4.21
\end{abstract}

\section{Corresponding author:}

Chide Okocha, Haematology Department, Nnamdi Azikiwe University Teaching Hospital, PMB 5025, Nnewi, Anambra State, Nigeria.

Email: onyichideokocha@yahoo.com

\section{Introduction}

Sickle cell disease (SCD) is a hereditary disease of hemoglobin $(\mathrm{Hb})$ due to the inheritance of an $\mathrm{S}$ gene on the $\beta$ globin chain. The disorder is due to a mutation at position six of the $\beta$ globin chain resulting in the substitution of glutamic acid by valine. Inheritance of the gene in a homozygous form or a compound heterozygous form

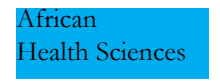

(C) 2018 Manafa et al. Licensee African Health Sciences. This is an Open Access article distributed under the terms of the Creative commons Attribution License (https://creativecommons.org/licenses/BY/4.0), which permits unrestricted use, distribution, and reproduction in any medium, provided the original work is properly cited. 
with another abnormal $\mathrm{Hb}$ often results in clinical disease. ${ }^{1}$ The disease is characterized by chronic debilitating complication often interrupted by episodes of exacerbated symptoms (crises) and periods of wellness (steady state). The disease is associated with increased morbidity and mortality and a significant reduction in life expectancy due to associated complications. ${ }^{2}$

SCD is highly prevalent in sub Saharan Africa with Nigeria bearing the highest burden. Nigeria has a prevalence rate of $2-3 \%$ which brings the affected population estimate between 3.2 and 4.8 million persons, with the national population estimate of 160 million. ${ }^{3,4}$

The chronic haemolytic and vaso-occlusive events that characterize the disease results in serious tissue-organ damage. The entire body tissue-organ-system is affected by the disease, however pancreatic complications are relatively rare. While most body organ complications in SCD have been widely studied, there is scarcity of publications on pancreatic complications in SCD because of its rarity. Balci et $\mathrm{ll}^{5}$ reviewed ultrasonographic findings in 102 SCD subjects in Antakya state hospital, Turkey, only 4 subjects had echogenic focus on the pancreas but no characteristic pancreatic disorder was reported. Ahmed et $\mathrm{al}^{6}$ also describe 4 case reports of acute pancreatitis in SCD subjects. They concluded that ischemic injury from vaso-occlusive events and biliary stones may underlie the pathology in SCD. Kumar et $\mathrm{al}^{7}$ also reported a rare case of acute pancreatitis complicated by pseudocyst formation. In a review of 52 malignancies in 49 SCD patients, William et al did not find any case of pancreatic carcinoma but reported cases of hepatoma and biliary tract carcinoma. ${ }^{8}$ These highlight the rarity of pancreatic disease in SCD despite the chronic ischaemia that characterize it. Carbohydrate antigen 19-9 is a glycoprotein that is expressed on pancreatic and biliary duct cells. ${ }^{9}$ In health, only trace amounts of the protein is found in plasma but in the setting of pancreatic or biliary tract disease such as pancreatitis, carcinoma of pancreas, biliary tract and carcinoma of the stomach, plasma levels rise exponentially. ${ }^{10}$ Evaluation of CA 19-9 levels in sickle cell disease patients, may be a valuable predictor of the onset of pancreatic and hepatobiliary disease including pancreatitis and pancreatic carcinoma.
CA19-9 levels is reported to have a sensitivity and specificity for pancreatic carcinoma in the range of $70-90 \%$ and $68-91 \%$ respectively ${ }^{11}$ hence its use as a tumor associated antigen. ${ }^{12}$ The hepatobiliary system is one of the common organs to be affected either directly from the sickling process or indirectly as a result of chronic hemolysis, leading to a high incidence of pigment gall stones, and multiple blood transfusions in sickle cell disease. ${ }^{13}$

Based on the above and chronic vaso-occlusive events in this disease, there is usually ischaemia of the pancreatic tissue, activation of the pancreatic enzymes and injury to the pancreas leading to pancreatitis; hence it is anticipated that CA 19-9 levels will be increased in plasma of these subjects. Acute pancreatitis is rarely included as a cause of abdominal pain in patients with sickle cell disease but when it occurs, it may result from biliary obstruction, but in other instances it might be a consequence of microvessel occlusion causing ischemia. ${ }^{6}$ There is paucity of study on CA 19-9 levels in SCD. We hypothesize that there is no significant difference in CA 19-9 antigen levels in Hb SS subjects compared to $\mathrm{HB}$ AS and $\mathrm{Hb}$ AA subjects.

We aimed to compare the levels of CA 19-9 in homozygous sickle cell disease subjects in steady state with those that have the trait (carriers) (Hb AS) and normal healthy subjects (Hb AA). To compare CA 19-9 levels in SCD subjects based on the disease severity scores and to correlate CA 19-9 levels with age, gender and severity scores of SCD subjects.

\section{Materials and methods}

This was a case control study conducted at the department of hematology, nnamdi azikiwe University Teaching Hospital Nnewi, Anambra state, Nigeria. The case group comprised $39 \mathrm{HbSS}$ subjects in steady state, 19 subjects with $\mathrm{Hb}$ AS and $\mathrm{Hb} 21 \mathrm{Hb}$ AA. Steady state was defined as an absence of febrile episodes, sickle cell crisis and blood transfusion for at least 2 weeks, 4 weeks and 3 months respectively prior to the study ${ }^{14}$ Sickle cell disease severity was calculated based on combination of 5 parameters including haemoglobin level, white cell count, number of hospital admissions, number of blood transfusions and complications. Scores $\leq 3$ were considered mild disease, $3-7$ moderate and $>7$ severe, as proposed by Okocha et $\mathrm{al}^{15}$ 
Inclusion criteria: The $\mathrm{Hb}$ SS subjects must be in steady state; all subjects must be within the age range of $18-60$ years. Excluded from the study were non $\mathrm{Hb}$ SS sickle cell disease subjects (such as $\mathrm{HbS} \beta$-thalassemia, HbSC, and others) and subjects below 17 and above 60 years of age. Also excluded were patients with known history of diabetes, pancreatitis and pancreatic cancer or hepatobiliary complications of SCD.

\section{Blood sample collection and storage}

About $5 \mathrm{ml}$ of venous blood was collected aseptically from each subject through venipuncture and $2 \mathrm{ml}$ dispensed into an EDTA container for the determination of genotype and full blood count. The remaining $3 \mathrm{ml}$ was dispensed into a plain container and centrifuged at $5000 \mathrm{rpm}$ for 5 minutes. The serum was then extracted and stored at $-20^{\circ} \mathrm{C}$ and later used for the estimation of CA 19-9 level. Normal reference for CA 19-9 are values $<37 \mathrm{U} / \mathrm{ml}$

Haemoglobin electrophoresis on cellulose acetate paper was used to determine $\mathrm{Hb}$ phenotype using the method of Kohn ${ }^{16}$ as described by Manafa et al. ${ }^{17}$ The levels of carbohydrate antigen was estimated on solid phase enzyme linked immunosorbent assay (ELISA) method as described by Steinberg et al. ${ }^{18}$

\section{Ethical consideration}

The ethical approval for this research was obtained from the Nnamdi Azikiwe University Teaching Hospital ethics committee (NAUTHEC). Informed consent of the subjects was sought and obtained prior to study.

\section{Statistical analysis}

Data obtained was analyzed with the IBM-SPSS statistical software version 21. Categorical variables were presented as frequency while numerical variables were presented as mean and standard deviation. The Student's t-test and the Analysis of Variance (ANOVA) was used for comparison of mean. Pearson's correlation coefficient was used to correlate CA 19.9 with age, gender and disease severity scores. Statistical significance was set at $\mathrm{P}$ values $<0.05$.

\section{Result}

A total of 79 subjects including $39 \mathrm{Hb} \mathrm{SS}, 19 \mathrm{Hb}$ AS and $21 \mathrm{Hb}$ AA subjects participated in the study. The mean ages of the study subjects were $25.9 \pm 6.6$ years, $24.5 \pm$ 4.7 years and $24.4 \pm 6.8$ years respectively. There was no significant difference in their mean ages $(p=0.589)$.

The subjects include 38 males and 41 females. There were 21, 10 and 10 females in the $\mathrm{Hb}$ SS, $\mathrm{Hb}$ AS and $\mathrm{Hb}$ AA sub-groups respectively. Disease severity was determined in $25 \mathrm{Hb}$ SS subjects. Eleven $\mathrm{Hb}$ SS subjects had moderately severe disease and 2 had severe disease.

Table 1 shows the mean, standard deviation and ranges of the carbohydrate antigen 19.9 in the study subjects. Overall, there was no significant difference in the mean CA 19.9 levels across study subjects however the post hoc analysis showed that the CA 19.9 levels was significantly higher in the $\mathrm{Hb} \mathrm{AA}$ subjects compared to the $\mathrm{Hb} \mathrm{AS}$ subjects $(p=0.035)$. 
Table 1: Age and CA 19-9 levels in study subjects

\begin{tabular}{|c|c|c|c|c|c|}
\hline Variable & Hb Phenotype & $\mathrm{N}$ & $\begin{array}{l}\text { Mean } \pm \text { SD } \\
(\mathrm{U} / \mathrm{ml})\end{array}$ & Range & $P$ value \\
\hline & $\mathrm{HbSS}$ & 39 & $25.9 \pm 6.6$ & $18-44$ & \\
\hline \multirow[t]{3}{*}{ Age } & $\mathrm{Hb}$ AS & 19 & $24.5 \pm 4.7$ & $18-35$ & 0.589 \\
\hline & $\mathrm{Hb} \mathrm{AA}$ & 21 & $24.4 \pm 6.8$ & $18-44$ & \\
\hline & $\mathrm{Hb} \mathrm{SS}$ & 39 & $13.6 \pm 7.6$ & $2.8-36.6$ & \\
\hline \multirow[t]{2}{*}{ CA 19.9} & $\mathrm{Hb}$ AS & 18 & $15.3 \pm 9.9$ & $2.0-41.0$ & 0.106 \\
\hline & $\mathrm{Hb} \mathrm{AA}$ & 20 & $20.0 \pm 15.9^{*}$ & $2.7-58.4$ & \\
\hline$* p=0.035$ & & & & & \\
\hline
\end{tabular}

Table 2 shows a comparison of CA 19.9 levels between males and females in each sub-group. Females across all the sub-groups had higher mean CA 19.9 levels compared to their male counterparts however the differences in the mean were not statistically significant.

Table 2: CA 19 - 9 levels based on sex distribution of study subjects

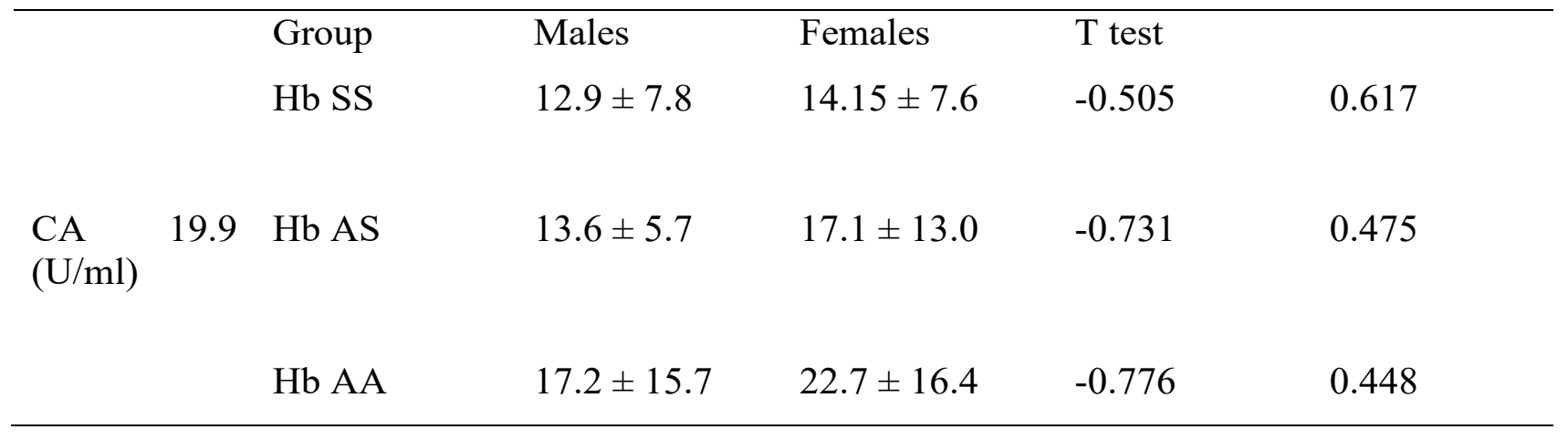

Table 3 shows the CA 19-9 levels in Hb SS subjects based on their disease severity. Subjects with severe disease had the highest level $17.2 \pm 15.7$, but the difference in mean was not statistically significant. 
Table 3. CA 19 - 9 levels based on SCD severity scores

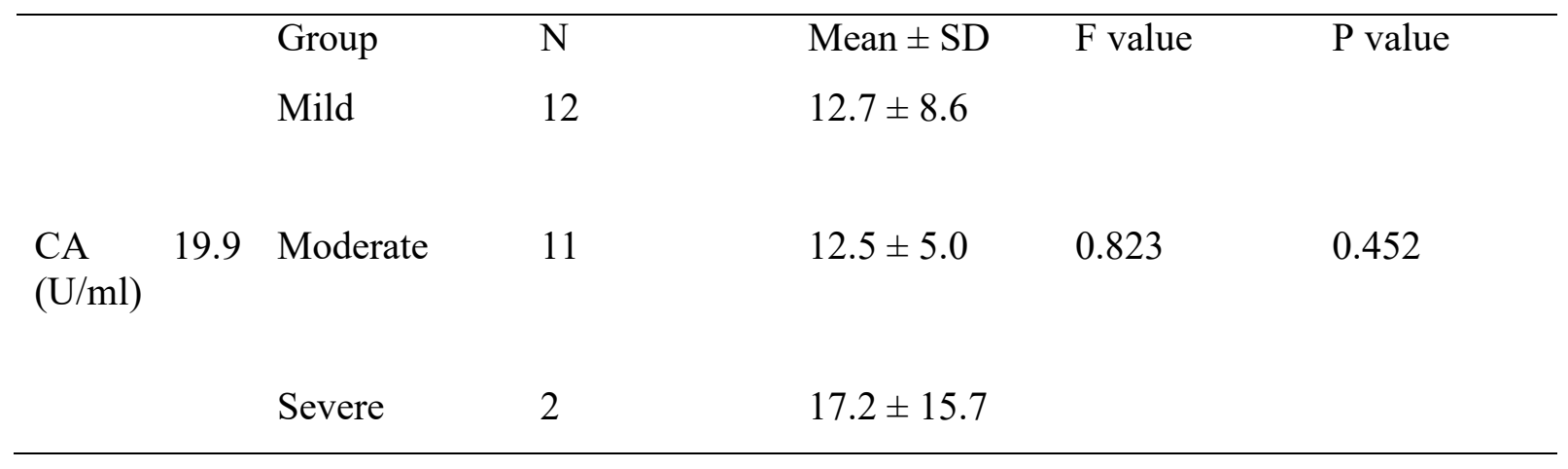

Posthoc analysis showed no significant difference between each of the groups.

Table 4 shows a correlation between the levels of CA 19.9 antigen with age, gender (female) and disease severity in the study subjects. There were weak correlations between
CA 19.9 and age, gender and disease severity in the Hb SS subjects. Similarly, there were weak correlations between CA 19.9 antigen levels with age and gender in the control groups ( $\mathrm{Hb} \mathrm{AS}$ and $\mathrm{Hb} \mathrm{AA})$.

Table 4: Correlation of CA 19 - 9 with age, gender and disease severity scores in study subjects

\begin{tabular}{|c|c|c|c|}
\hline \multirow[t]{2}{*}{ Group } & & \multicolumn{2}{|c|}{ CA $19.9(\mathrm{U} / \mathrm{ml})$} \\
\hline & & $\mathrm{R}$ & $P$ value \\
\hline & Age & 0.241 & 0.139 \\
\hline \multicolumn{4}{|l|}{$\mathrm{Hb} \mathrm{SS}$} \\
\hline & Gender $(F)$ & 0.130 & 0.429 \\
\hline & Disease severity & 0.090 & 0.669 \\
\hline \multirow[t]{2}{*}{$\mathrm{Hb} \mathrm{AS}$} & Age & 0.114 & 0.653 \\
\hline & Gender $(F)$ & 0.054 & 0.833 \\
\hline \multirow[t]{2}{*}{$\mathrm{Hb} \mathrm{AA}$} & Age & -0.048 & 0.841 \\
\hline & Gender (F) & 0.208 & 0.379 \\
\hline
\end{tabular}




\section{Discussion}

Ca 19-9 is a surrogate marker for pancreatic and biliary tract diseases especially carcinoma. Its levels is also elevated in other benign medical conditions of the pancreas and biliary tract including acute and chronic pancreatitis. Clinical obvious pancreatic disease are relatively rare in SCD however few case reports have been published. ${ }^{5-8}$ Furthermore there are rarity of studies on CA 19-9 levels in SCD subjects. In the index study, the mean CA $19-9$ levels was significantly elevated in the $\mathrm{Hb} \mathrm{AA}$ controls compared to the Hb SS group and did not differ between $\mathrm{Hb} \mathrm{SS}$ and $\mathrm{Hb}$ AS subjects. This suggests that the presence of an $\mathrm{S}$ haemoglobin may be associated with reduced pancreatic injury and damage hence the relatively low CA $19-9$ activity. Although we do not know the mechanism by which this happens, the fact that pancreatitis and pancreatic disease is rare in SCD despite the high incidence of gall stones ${ }^{7}$ seems to agree with our findings.

We observed that between males and females in each subgroup, there was no significant difference in the mean CA $19-9$ levels though the females had higher values than the males. Available data from studies by Selcukbiricik et $\mathrm{al}^{19}$, and Gui-Bin ${ }^{20}$ indicate that there was no significant difference between male and females however the males in their study had higher mean values.

We also observed that there was no difference in the mean CA 19 - 9 levels based on disease severity. Though subjects with severe disease had the highest value, followed by those with mild disease, this trend did not show any characteristic pattern. However there were relatively few subjects with severe disease that participated in the study. Correlating CA 19 - 9 levels with age, gender and disease severity, there appeared to be a positive correlation with age and female gender in $\mathrm{Hb} \mathrm{SS}$ and $\mathrm{Hb} \mathrm{AS}$, but in $\mathrm{Hb}$ $\mathrm{AA}$, there was a negative correlation with age. However these correlations were not statistically significant. In the same manner, Malaguarneraa et $\mathrm{al}^{21}$, Leichsenring et $\mathrm{al}^{22}$ and Pandiaraja et $\mathrm{al}^{23}$ reported positive correlation with gender however it was not significant statistically. Our findings in relation to correlation with age was similar to the observations of Pandiaraja ${ }^{23}$ but differed from those Duraker et $\mathrm{al}^{24}$ and Sisik et al. ${ }^{25}$ who reported significant correlation with age.
Conclusively, CA $19-9$ is significantly decreased in SCD compared to the normal haemoglobin genotype population. There is no difference in CA $19-9$ levels between male and females. Its level did not also change significantly with disease severity. There was no significant correlation with age, gender and disease severity. This work is limited by the fact that it was done in one centre. These findings should be confirmed preferably by a multi-centre study that has a higher sample size.

\section{Conflict of interest}

The authors have no conflict of interest to declare.

\section{References}

1. Adewoyin AS. Management of sickle cell disease: A review for physician education in Nigeria (sub Saharan Africa). Anemia. 2015:791498

2. Chijioke A, Kolo PM. The longevity and clinical pattern of adult sickle cell anaemia in Ilorin. Eur J Sci Res. 2009; 32:528 532.

3. Omotade OO, Kayode CM, Falade SL, Ikpeme S, Adeyemo AA, Akinkugbe FM. Routine screening for sickle cell haemoglobinopathy by electrophoresis in an infant welfare clinic. West Afr J Med. 1998; 17:91 94.

4. Ndujihe C. Population: How many are we in Nigeria. Lagos: A Publication of Nigerian Vanguard; 2013.

5. Balc1 A, Karazincir S, Sangün O, Gali E, Daplan T, Cingiz $\mathrm{C}$ et al. Prevalence of abdominal ultrasonographic abnormalities in patients with sickle cell disease. Diagn Interv Radiol. 2008; 14:133-137.

6. Ahmed S, Siddiqui AK, Siddiqui RK, et al.: Acute pancreatitis during sickle cell vaso-occlusive painful crisis. $\mathrm{Am}$ J Hematol. 2003, 73:190-3. 10.1002/ajh.10344. PubMed

7. Kumar A, Posner G, Marsh F, Bellvue R, Dosik H. Acute pancreatitis in sickle cell crisis. Journal of the National Medical Association. 1989; 81(1): 91 - 92.

8. Plemenos MF, Dimas C, Kotsios A, Gennatas K, Kondi-Pafiti A. Prognostic significance of the immunohistochemical localization and serological detection of CA199 tumor antigen in colon carcinoma. Journal of Balkan Union of Oncology. 2004; 9(1): 73-76.

9. Safi F, Berger HG, Bittner R, Buchler M, Krautzberger. CA 19-9 and pancreatic adenocarcinoma. Cancer. 1986; 57: 779-783 PubMed .10.

10. Maestranzi S, Przemioslo R, Mitchell H, Sherwood $\mathrm{RA}$. The effect of benign and malignant liver disease on 
the tumour markers CA19-9 and CEA. Annals of Clinical Biochemistry. 1998; 35(1): 99-103.

11. Goonetilleke KS, Siriwardena AK. Systematic review of carbohydrate antigen (CA19-9) as a biochemical marker in the diagnosis of pancreatic cancer. European Journal of Surgical Oncology. 2007; 33: 266-270.

12. Koprowski H, Steplewski Z, Mitchell K. Colorectal carcinoma antigens detected by hybridoma antibodies. Somatic Cell and Molecular Genetics.1979; 5:957-972.

13. Issa H, Al-Salem A. Hepatobiliary manifestations of sickle cell anemia. Gastroenterology Research. 2010; 3(1): 1-8. 14. Okocha C, Manafa P, Ozomba J, Ulasi T, Chukwuma G, Aneke J. C-reactive Protein and Disease Outcome in Nigerian Sickle Cell Disease Patients. Annals of Medical and Health Sciences Research. 2014;4(5):701-705. doi:10.4103/2141-9248.141523.

15. Okocha E C, Manafa O P, Aneke C J, Onwuzuruike E C, Ibeh C N, Chukwuma O G. Serum superoxide dismutase activity: A predictor of disease severity in nigerian sickle cell anemia patients in steady state. Med J DY Patil Univ. [serial online] 2017 [cited 2017 Dec 15];10:40611. Available from: http://www.mjdrdypu.org/text. asp?2017/10/5/406/218203

16. Kohn J. Cellulose-acetate electrophoresis and immune-diffusion techniques. In: Chromatographic and electrophoretic techniques, vol.II. zone electrophoresis. New York; Interscience. 1957, 56-90.

17. Manafa PO, Osmond EO, Onyenekwe CC, Okeke CO, Chukwuma GO, Ihim AC et al. Assessment of tumour necrosis factor-alpha $(\mathrm{TNF}-\alpha)$ and creatinine levels In Echis Ocellatus bite victims in Jos metropolis, Nigeria. European Scientific Journal. 2016; 12(21): 1857 - 7881
18. Steinberg WW, Gelfand R, Anderson KK. Comparison of the sensitivity and specificity of CA19-9 and carcinoembryonic antigen assays in detecting cancer of the pancreas. Gastroenterology. 1986; 90:343-349 PubMed .

19. Selcukbiricik F, Bilici A, Tural D, Erdamar S, Soyluk O, Buyukunal, E., Demirelli, F., Serdengecti, S. Are high initial CEA and CA19-9 levels associated with the presence of K-ras mutation in patients with metastatic colorectal cancer?. Tumor Biology. 2013; 34(4):2233-2239. PubMed 20. Gui-BinB. Clinical value of serum cancer antigen 19-9 as a tumor screening marker among healthy individuals. Journal of Balcan Union of Oncology. 2015; 20(6): 1612-1616. 21. Malaguarnera G, Paladina I, Giordano M, Malaguarnera M, Bertino G, Berretta, M. Serum markers of intrahepatic cholangiocarcinoma. Disease Markers. 2013; 34: 219- PubMed ;228.

22. Leichsenring M, Rueckel B, Meissner P, Kratzer, W. (2014). The variability of carbohydrate antigen 19-9 levels in cystic fibrosis patients. Cystic Fibrosis Journal. 2014; 189-190

23. Pandiaraja J, Viswanathan S, Antomy TB, Thirumuruganand S, Kumaresan DS. The Role of CA19-9 in Predicting Tumour Resectability in Carcinoma Head of Pancreas. Journal of Clinical and Diagnostic Research. 2016; 10(3): 6-9.

24. Duraker N, Hot S, Polat Y. CEA, CA 19-9, and CA 125 in the differential diagnosis of benign and malignant pancreatic diseases with or without jaundice. Journal of Surgical Oncology. 2007; 95(2):142-147

25. Sisik A, Kaya M, Bas G, Basak F, Alimoglu O. CEA and CA19-9 are still valuable markers for the prognosis of Colorectal and Gastric Cancer Patients. Asian Pacific Journal of Cancer Prevention. 2013; 14(7):4289-4294. 